\title{
Autophagy in human skin squamous cell carcinoma: Inhibition by 3-MA enhances the effect of 5-FU-induced chemotherapy sensitivity
}

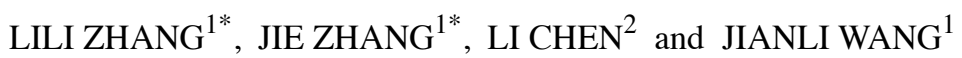 \\ ${ }^{1}$ Department of Dermatology, Affiliated Hospital of Nantong University; \\ ${ }^{2}$ Department of Pathology Anatomy, Medicine School of Nantong University, \\ Nantong, Jiangsu 226001, P.R. China
}

Received June 17, 2015; Accepted July 31, 2015

DOI: $10.3892 /$ or.2015.4302

\begin{abstract}
Autophagy is an intracellular multi-step catabolic degradation process that involves the degradation and recycling of cellular proteins and cytoplasmic damaged organelles to maintain cellular homeostasis and reduction of metabolic stress. Numerous studies have indicated the importance of autophagy in cancer, but the role of autophagy in human skin squamous cell carcinoma (SSCC) development and response to therapy it is still unclear. In the present study, we investigated the role of autophagy in SSCC and the relationship with chemotherapy sensitivity. The present study demonstrated that autophagy related gene the microtubuleassociated protein 1 light chain 3 (LC3) expression was low in SSCC. The negative correlation with $\mathrm{Bcl} 2$ and survivin, and the chemotherapy drug 5-FU increased the level of autophagy and the autophagy inhibitor 3-MA inhibited this effect in SSCC cells, time- and dose-dependently. When SSCC cells were treated first with 3-MA and then with 5-FU, the inhibition of proliferation, migration, invasion and apoptosis of SSCC cells was enhanced. Our results suggested the possibility of autophagy as a potential target in SSCC therapy and 3-MA and 5-FU combination treatment may be an effective SSCC therapy via autophagy modulating.
\end{abstract}

Correspondence to: Dr Jianli Wang, Department of Dermatology, Affiliated Hospital of Nantong University, 20 Xisi Road, Nantong, Jiangsu 226001, P.R. China

E-mail: pfkwang@163.com

Dr Li Chen, Department of Pathology Anatomy, Medicine School of Nantong University, 19 Qixiu Road, Nantong, Jiangsu 226001, P.R. China

E-mail: bl1@ntu.edu.cn

${ }^{*}$ Contributed equally

Key words: autophagy, skin squamous cell carcinoma, microtubuleassociated protein 1 light chain 3,3-methyladenine, 5-fluorouracil

\section{Introduction}

Human skin squamous cell carcinoma (SSCC) accounts for more than $15 \%$ of malignant epithelial tumors, it is a malignant tumor that can occur in normal skin, but commonly evolves from precursor lesions. SSCC arising in ulcers is a rare and often aggressive cutaneous malignancy that arises from chronic wounds or old scars (1), but the mechanism is unclear. Autophagy is the basic catabolic mechanism that involves cell degradation of unnecessary or dysfunctional cellular components through the actions of lysosomes, and in recent years, numerous studies showed that autophagy is associated with the development of many types of cancers, such as colorectal cancer (2), gastrointestinal stromal tumor (3), prostate cancer (4), chronic myelogenous leukemia (5) and lymphoma (6). Moreover, pharmacological modulation of autophagy in tumors may be an important anticancer therapy, as is supported by the use of autophagy inhibitors in a large number of clinical trials and currently as a treatment for various types of cancers that are generally very aggressive or resistant to therapy (7). However, the role of autophagy and the mechanisms remain unclear in SSCC.

Microtubule-associated protein 1 light chain 3 (LC3) is the mammal homologous of Atg8, it locates in the membrane of the autophagosome, it is a good marker of the process of autophagy membrane dynamics (8). In the present study, we evaluated the expression level of LC3, Bcl2 $(9,10)$ and survivin (an anticancer gene) (11) in SSCC clinical tissues. Then we assessed clinical and pathological roles of LC3 in SSCC, and the relationship between LC3 and Bcl2 or survivin were analyzed. Furthermore, we used the chemotherapy drug 5-fluorouracil (5-FU) and the autophagy inhibitor 3-methyladenine (3-MA) to clarify the biological functions of autophagy on the proliferation, motility, invasion and apoptosis of SSCC cells. The results in SSCC suggested the possibility of autophagy as a potential target in SSCC therapy. Furthermore, autophagy inhibited by 3-MA in SSCC was able to enhance effect of 5-FU-induced chemotherapy sensitivity.

\section{Materials and methods}

Clinical specimens and immunohistochemical staining. A total of 100 cases of paraffin-embedded tissue of SSCC biopsy 
specimens were obtained from the Department of Pathological Anatomy of Haimen People's Hospital. The samples were collected from the patients aged 25-90 years, and were histologically confirmed with no radiotherapy and/or chemotherapy before operation. Ten cases of surgical margin from the patients with breast cancer were obtained as control (provided by the Department of Pathological Anatomy of Nantong University Affiliated Hospital). All of the patients were staged using the seventh edition of the International Union Against Cancer tumor-node-metastasis (TNM) staging system. The present study was approved by the Institute Research Ethics Committee of the Nantong University Affiliated Hospital of China.

Tissue chip and hematoxylin and eosin $(H \& E)$ staining. Tissue chips were constructed by the Department of Pathological Anatomy of Nantong University. Briefly, all tissues were reviewed and representative areas were marked in paraffin blocks. Two cylindrical tissue cores were removed from the donor blocks and transferred to the recipient paraffin blocks, and their planar array positions were noted. Consecutive sections (4- $\mu \mathrm{m}$ thick) were cut from the array blocks and placed on adhesion microscope slides for H\&E and/or immunohistochemical staining for observation.

Immunohistochemistry. Paraffin sections were deparaffinized in xylene, rehydrated in alcohol concentration gradient, increasing the accessibility of the antigens in boiling citrate buffer ( $\mathrm{pH}$ 6.0) for $20 \mathrm{~min}$ and blocking endogenous peroxidase activity in $0.3 \% \mathrm{H}_{2} \mathrm{O}_{2}$ at $37^{\circ} \mathrm{C}$ for $10 \mathrm{~min}$. The sections were blocked with non-immune goat serum at $37^{\circ} \mathrm{C}$ for $10 \mathrm{~min}$. Then, the sections were incubated with the primary antibodies: anti-LC3 (1:100 dilution; Abcam, USA), anti-Bcl2 (1:50 dilution), anti-survivin (1:50 dilution) (both from Maixin Biotech, China) at $37^{\circ} \mathrm{C}$ for $30 \mathrm{~min}$, and then at $4^{\circ} \mathrm{C}$ overnight. The sections were washed by phosphate-buffered saline (PBS) for $5 \mathrm{~min}$ three times, then incubated by goat anti-rabbit or mouse IgG-HRP (1:100 dilution; Boster, China), immunostaining was performed using the diaminobenzidine (DAB) substrate chromogen solution and hematoxylin staining were visualized with the chromogen DAB. The sections were analyzed by two qualified independent investigators. Five high-power fields of views per section were captured and representative images were selected and recorded.

The immunohistochemistry scoring results were evaluated independently by the pathologists without knowing the patients clinicopathological outcomes, and then the results were analyzed according to the intensity of the staining and the relative abundance of positive cells. The positive expression of LC3, Bcl2 and survivin were evaluated by cytoplasm/nucleus with yellow staining. Scores were assigned for the intensity and percentage of positive staining. Briefly, the IRS assigns subscores for immunoreactive distribution (0-4) and intensity (0-3), and the subscores were multiplied to yield the IRS score.

Cell lines and cell culture. A431 cells were cultured in Dulbecco's modified Eagle's medium (DMEM) supplemented with $10 \%$ fetal bovine serum (FBS) (Gibco, USA). The cell line was maintained at $37^{\circ} \mathrm{C}$ in a humidified incubator with $5 \% \mathrm{CO}_{2}$. A431 cells were kindly provided by Professor
Tianwen Gao of Xijing Hospital Affiliated to The Fourth Military Medical University.

Cell proliferation assay. The proliferation ability of A431 cells was measured by MTT method. A431 cells $\left(1 \times 10^{3}\right.$ cells/well $)$ were plated into a 96 -well plate for $24 \mathrm{~h}$, the cells were treated with 5-fluorouracil (5-FU) (Shandong Qilu Pharmaceutical, China) at the concentrations of $0.1,1,10$ and $100 \mu \mathrm{g} / \mathrm{ml} ; 3-\mathrm{MA}$ (Sigma-Aldrich, USA) treated groups at concentrations of 2, 4 and $8 \mathrm{mmol} / \mathrm{l}, 3-\mathrm{MA}$ and 5-FU combined groups: i) 3-MA+ 5-FU, the cells were treated with the optimum concentration of $3-\mathrm{MA}$ at $37^{\circ} \mathrm{C}$ for $1 \mathrm{~h}$, then the solution was removed and treated with the optimum concentration of 5-FU; ii) 5-FU+3MA, the cells were treated with the optimum concentration of $5-\mathrm{FU}$ at $37^{\circ} \mathrm{C}$ for $1 \mathrm{~h}$ first, then the solution was removed and treated with the optimum concentration of 3-MA. Both groups were incubated at $37^{\circ} \mathrm{C}$ for $24 \mathrm{~h}$. MTT $(10 \mu \mathrm{l})(0.5 \mathrm{mg} /$ $\mathrm{ml}$; Aladdin Reagent, China) reagents were added to each well of the 96-well plate containing $100 \mu \mathrm{l}$ culture medium and the plate was incubated for $4 \mathrm{~h}$ at $37^{\circ} \mathrm{C}$, then $150 \mu \mathrm{l}$ dimethylsulfoxide (DMSO) was added into each well, and incubation continued for $10 \mathrm{~min}$ at $37^{\circ} \mathrm{C}$. The optical density (OD) was measured at $570 \mathrm{~nm}$ using a microplate reader (Bio-Rad, USA).

Real-time quantity PCR (RT-qPCR). The mRNA expression of LC3 in A431 cells with different treatments were detected by RT-qPCR. A431 cells ( $1 \times 10^{3}$ cells/well) were plated into a 96-well plate for $24 \mathrm{~h}$, the cells were treated as: 1 and $10 \mu \mathrm{g} / \mathrm{ml}$ 5-FU; 2 and 4 mmol/1 3-MA (Sigma-Aldrich); untreated group as control. Then, the cells were incubated at $37^{\circ} \mathrm{C}$ for $24 \mathrm{~h}$.

Total RNA of cells were extracted using a RISO ${ }^{\mathrm{TM}}$ RNA extraction reagent according to the manufacturer's procedure and then submitted to a RT-qPCR reaction: $12.5 \mu \mathrm{l}$ of 2 xMaster Mix (Biomics Biotechnology, China), $0.5 \mu \mathrm{l}$ of each forward and reverse primers mix (10 $\mu \mathrm{mol} / 1$ each), $0.5 \mu \mathrm{l}$ of $50 \mathrm{X}$ SYBR-Green I and $4 \mu 1$ RNA as template. Then, the samples were subjected to reverse transcription for $30 \mathrm{~min}$ at $42^{\circ} \mathrm{C}$ and initially denatured for $5 \mathrm{~min}$ at $95^{\circ} \mathrm{C}$, and then 45 cycles of amplification with the following cycling conditions: $95^{\circ} \mathrm{C}$ denature for $20 \mathrm{sec}, 58^{\circ} \mathrm{C}$ annealing for $30 \mathrm{sec}$ and $72^{\circ} \mathrm{C}$ extension for $30 \mathrm{sec}$. Glyceraldehyde-3-phosphate dehydrogenase (GAPDH) served as an internal control. All the primers were designed and obtained from Biomics Biotechnology, the primer sequence of LC3 was forward, 5'-CCTTCTTCCTGC TGGTGAAC-3' and reverse, 5'-TCTCCTGCTCGTAGATG TCC-3'; the primer sequence of $\beta$-actin forward, 5'-TGCAC CACCAACTGCTTAGC-3' and reverse, 5'-GGCATGGACTG TGGTCATGAG-3'. The experiment was performed in triplicate. The results were analyzed by $2^{-\Delta \Delta \mathrm{Ct}}$ method (12).

Western blotting. The protein level of LC3 in A431 cells with different treatments were detected by western blotting. A431 cells ( $4 \times 10^{5}$ cells/well) were plated into a 6 -well plate for $24 \mathrm{~h}$, the cells were treated as described in RT-qPCR.

The cells were harvested at $24 \mathrm{~h}$ post-treatments, and then lysed in ice-cold RIPA buffer (Pierce, USA). The appropriate amount of total cell lysates per lane were separated with SDS-polyacrylamide gel electrophoresis (SDS-PAGE) and electroblotted onto polyvinylidine difluoride (PVDF) filter membranes (Millipore, USA), followed by blocking 
with $5 \%$ skim milk in TBST $(20 \mathrm{mM}$ Tris, $150 \mathrm{mM} \mathrm{NaCl}$, $0.05 \%$ Tween-20, $\mathrm{pH} 7.5$ ) for $2 \mathrm{~h}$ at room temperature, then the membrane was incubated with primary antibody of rabbit anti-human LC3 (1:500 dilution; Abcam), and mouse antihuman $\beta$-actin (1:500 dilution; Boster) as internal control. The membranes were then washed in TBST and incubated with a goat anti-mouse HRP-conjugated secondary antibody (1:1,000 dilution; Boster) at room temperature for $2 \mathrm{~h}$. The specific proteins were detected with Luminol ECL reagent; the membranes were exposed to a film (Kodak, USA).

Monodansylcadaverine (MDC) fluorescent staining. MDC fluorescent staining was performed according to the method previously described by Biederbick et al (13). Briefly, a total of $5 \times 10^{4}$ A431 cells were cultured on a small round slide in a 24-well plate at $37^{\circ} \mathrm{C}$ overnight in a humidified incubator with $5 \% \mathrm{CO}_{2}$. When cells reached 50-60\% confluence, they were treated with different methods: 5-FU, 3-MA, 3-MA+5-FU, 5-FU+3-MA and untreated group as control. Then, the treated cells were incubated at $37^{\circ} \mathrm{C}$ for $24 \mathrm{~h}$. After the slides were washed by PBS for 5 min twice, $0.05 \mathrm{mmol} / 1 \mathrm{MDC}$ (SigmaAldrich) was added to each slide, and incubated at $37^{\circ} \mathrm{C}$ for $1 \mathrm{~h}$ protected form light, and then washed with PBS, the slides were fixed with $4 \%$ paraformaldehyde for $15 \mathrm{~min}$, after washed with PBS and mounted. The cells were observed by immunofluorescence microscopy.

Immunocytochemistry (ICC) and confocal laser scanning microscopy. The method of cells plating and treatments were as in the MDC fluorescent staining. Following the different treatments, the cells were fixed for 30 min with $4 \%$ paraformaldehyde and permeabilized for $15 \mathrm{~min}$ with $0.5 \%$ Triton X-100, after washed by PBS three times, then blocked with $1 \%$ bovine serum albumin (BSA) for $30 \mathrm{~min}$ at room temperature. Subsequently, cells were incubated overnight at $4^{\circ} \mathrm{C}$ with anti-LC3 antibody (1:50 dilution; Abcam), and then with TRITC-conjugated goat anti-rabbit IgG for $2 \mathrm{~h}$ at $37^{\circ} \mathrm{C}$. Hoechst $33258(10 \mathrm{mg} / \mathrm{ml})$ (Life Technologies, USA) was used for cell nuclei stain for $30 \mathrm{~min}$, then washed in PBS and mounted in Antifade mounting medium (Beyotime, China). The cells were observed by immunofluorescence microscopy.

Transmission electron microscopy. A431 cells were plated and treated as previously described. Before collection, the cells were replaced with fresh medium, and incubated at $37^{\circ} \mathrm{C}$ for 15 min, after being washed in PBS, the cells were collected by centrifugation at $1,000 \mathrm{rpm}$ for $10 \mathrm{~min}$, and then fixed in ice-cold $2.5 \%$ glutaraldehyde in PBS, post-fixed $2 \mathrm{~h}$ in $1 \%$ $\mathrm{OsO}_{4}$ with $0.1 \%$ potassium ferricyanide, dehydrated through a graded series of ethanol (50-90\%) following incubation in a mixture of $90 \%$ ethanol and $90 \%$ acetone (1:1) for $20 \mathrm{~min}$, and then incubated in $90 \%$ acetone for $15-20 \mathrm{~min}$ at $4^{\circ} \mathrm{C}$. After the cells were embedded and fixed, they were cut into sections (50-60 nm). Uranyl acetate (3\%) and lead citrate stain was used for examination with a transmission electron microscope (JEOL, Japan).

Hoechst staining. The method of cell plating and treatments were as in MDC fluorescent staining. Following the different treatments, the cells were fixed for 30 min with $4 \%$ paraformaldehyde, then washed with PBS for 5 min twice. Hoechst $33258(10 \mathrm{mg} / \mathrm{ml})$ (Life Technologies) was used for cell nuclei stain for $30 \mathrm{~min}$, after washing in PBS and mounted in Antifade mounting medium. The cells were observed by immunofluorescence microscopy. Cell apoptotic index (AI) was obtained by counting the number of apoptotic cells with condensed nuclei among the cells in six to eight randomly selected view fields.

Cell migration assay. The migration of A431 cells with different treatments was detected by wound-healing assay. Cells were plated and treated as previously described into a 12-well plate at the density of $1 \times 10^{6}$ cells/well. After $48 \mathrm{~h}$, wound was made through confluent monolayer cells with a pipette tip and cells were washed with PBS and then DMEM medium with no FBS. Images of cells were captured at 0,24 and $48 \mathrm{~h}$ to monitor cell movements.

Cell invasion assay. The invasion ability of A431 cells affected by different treatments was determined by Matrigel Transwell assay. Before treatment, Transwell chambers (Corning, USA) were treated with $20 \mu \mathrm{l}$ Matrigel (BD, USA) (1:8 diluted in DMEM medium) per well at $37^{\circ} \mathrm{C}$ for $1 \mathrm{~h}$. A431 cells were treated with $0.25 \%$ trypsin and suspended in DMEM containing 5-FU and/or 3-MA, $100 \mu \mathrm{l}$ cell $\left(1 \times 10^{5}\right.$ cells) suspensions were added into each upper chamber and $500 \mu 1$ DMEM containing 10\% FBS, and incubated at $37^{\circ} \mathrm{C}$ for $24 \mathrm{~h}$. The cells on the top surface of the membrane were carefully removed with a cotton swab. Cells on the Transwell chambers were fixed by $75 \%$ ethanol for 10 min, washed with PBS and then stained by $0.2 \%$ crystal violet for $10 \mathrm{~min}$, after washing with PBS twice, the invaded cells on the bottom surface of the membrane were counted in five random fields (magnification, x100) per membrane, and the average number of migrated cells per field was calculated.

Statistical analysis. The experiments were independently performed three times, the results are shown as mean \pm standard deviation (SD), and statistical analyses were performed using SPSS 19.0 software. The differences between groups were compared using Student's t-test, one way ANOVA, $\chi^{2}$ test and Pearson's correlation analysis to assess statistical significance. All P-values were based on a two-sided statistical analysis and $\mathrm{P}<0.05$ was considered to indicate statistical significance.

\section{Results}

The expression of LC3 in the SSCC and the association of Beclin-1 expression with clinicopathological factors of SSCC. The expression of LC3, Bcl2 and survivin in 100 cases of SSCC tissues and 10 cases of surgical margin from breast cancers on tissue chip were detected by immunohistochemical analysis (Fig. 1). A significant difference was observed in LC3 expression between SSCC and control samples $(\mathrm{P}<0.005)$ (Table I).

The results showed that the positive staining of LC3 was $56 \%$, while $\sim 100 \%$ in normal tissues $(\mathrm{P}<0.005)$, the positive staining of $\mathrm{Bcl} 2$ was $85 \%$, while no expression in normal 


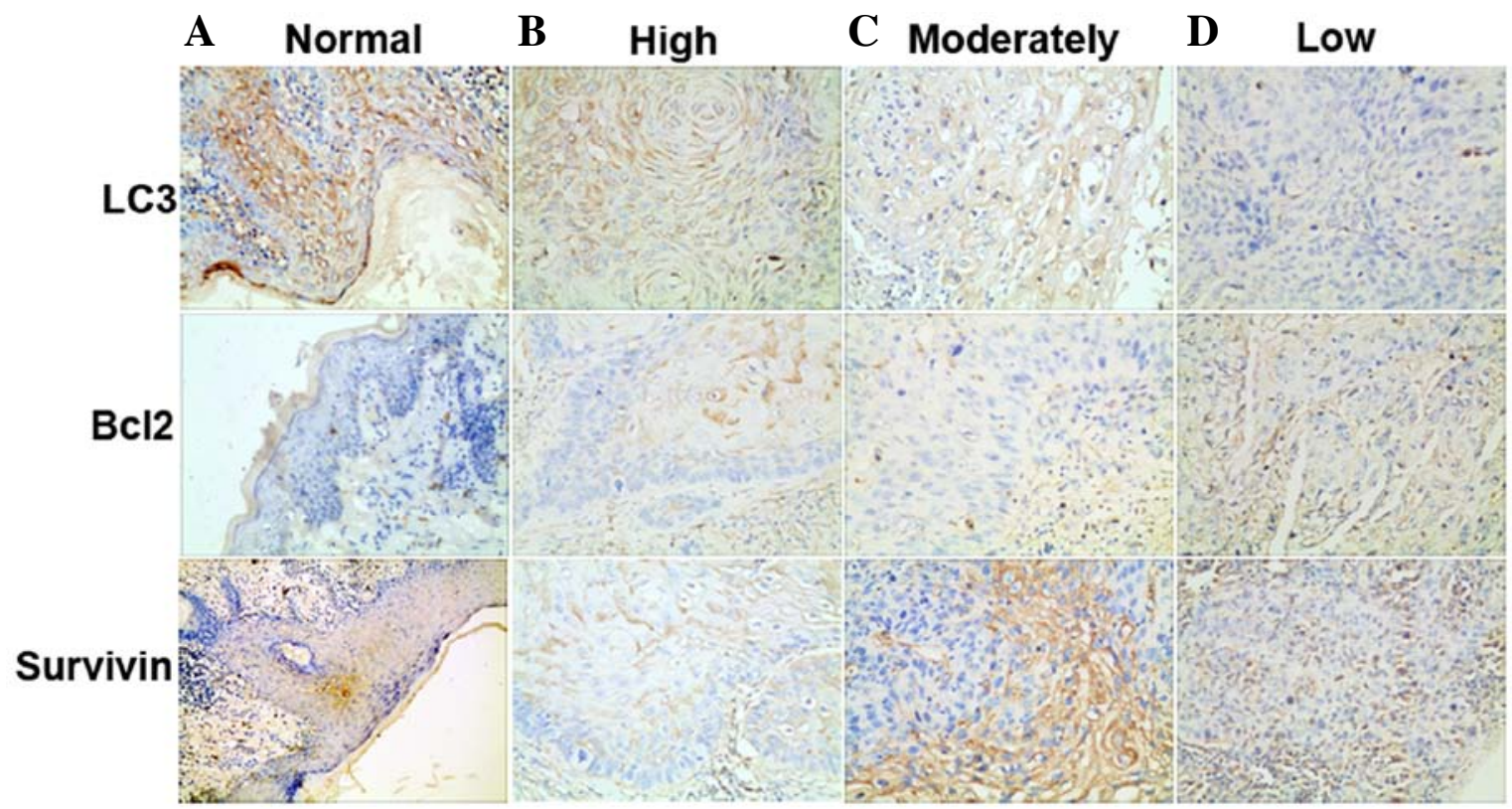

Figure 1. The expression of LC3, Bcl2 and survivin in SSCC tissue chip. (A) Normal tissues (magnification, 400x). (B) High differentiation SSCC tissues (magnification, x400). (C) Moderately differentiated SSCC tissues (magnification, x400). (D) Low, poorly differentiated SSCC tissues (magnification, x400).

Table I. Correlation between LC3 expression and clinicopathological characteristics in SSCC.

\begin{tabular}{|c|c|c|c|c|c|c|}
\hline \multirow{2}{*}{$\begin{array}{l}\text { Clinicopathological } \\
\text { parameters }\end{array}$} & \multirow[b]{2}{*}{ No. case } & \multicolumn{3}{|c|}{ LC3 } & \multirow[b]{2}{*}{$\chi^{2}$} & \multirow[b]{2}{*}{ P-value } \\
\hline & & $(-)$ & $(+)$ & $(++)$ & & \\
\hline \multicolumn{7}{|l|}{ Age (years) } \\
\hline$\leq 63$ & 53 & 24 & 19 & 10 & \multirow[t]{2}{*}{0.310} & \multirow[t]{2}{*}{0.857} \\
\hline$>63$ & 47 & 20 & 16 & 11 & & \\
\hline \multicolumn{7}{|l|}{ Location/site } \\
\hline Head and face & 70 & 32 & 23 & 15 & \multirow[t]{4}{*}{1.246} & \multirow[t]{4}{*}{0.975} \\
\hline Body & 6 & 2 & 3 & 1 & & \\
\hline The limbs & 5 & 2 & 2 & 1 & & \\
\hline Genitalia & 19 & 8 & 8 & 3 & & \\
\hline \multicolumn{7}{|l|}{ Thickness (mm) } \\
\hline$\leq 5$ & 83 & 31 & 37 & 15 & \multirow[t]{2}{*}{8.777} & \multirow[t]{2}{*}{$0.012^{\mathrm{a}}$} \\
\hline$>5$ & 17 & 13 & 3 & 1 & & \\
\hline \multicolumn{7}{|l|}{ TNM stages } \\
\hline I & 40 & 10 & 20 & 10 & \multirow[t]{4}{*}{16.053} & \multirow[t]{4}{*}{$0.013^{\mathrm{a}}$} \\
\hline II & 49 & 26 & 18 & 5 & & \\
\hline III & 6 & 3 & 3 & 0 & & \\
\hline IV & 5 & 5 & 0 & 0 & & \\
\hline \multicolumn{7}{|l|}{ Types } \\
\hline Typical & 54 & 15 & 25 & 13 & \multirow{4}{*}{13.506} & \multirow[t]{4}{*}{$0.036^{\mathrm{a}}$} \\
\hline Acantholytic SCC & 23 & 14 & 8 & 2 & & \\
\hline Spindle cell SCC & 12 & 7 & 3 & 2 & & \\
\hline Verrucous SCC & 11 & 8 & 3 & 0 & & \\
\hline \multicolumn{7}{|c|}{ Lymph node metastasis } \\
\hline Yes & 5 & 0 & 0 & 0 & \multirow[t]{2}{*}{6.699} & \multirow[t]{2}{*}{$0.036^{\mathrm{a}}$} \\
\hline No & 95 & 39 & 44 & 12 & & \\
\hline
\end{tabular}

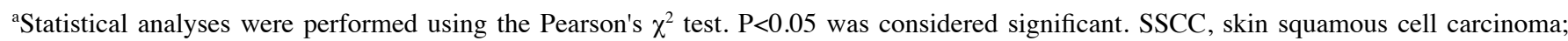
TNM, tumor-node-metastasis. 
A

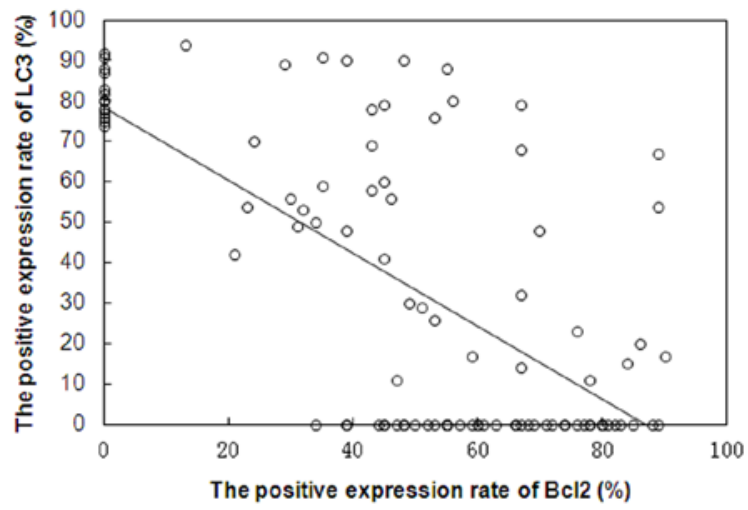

B

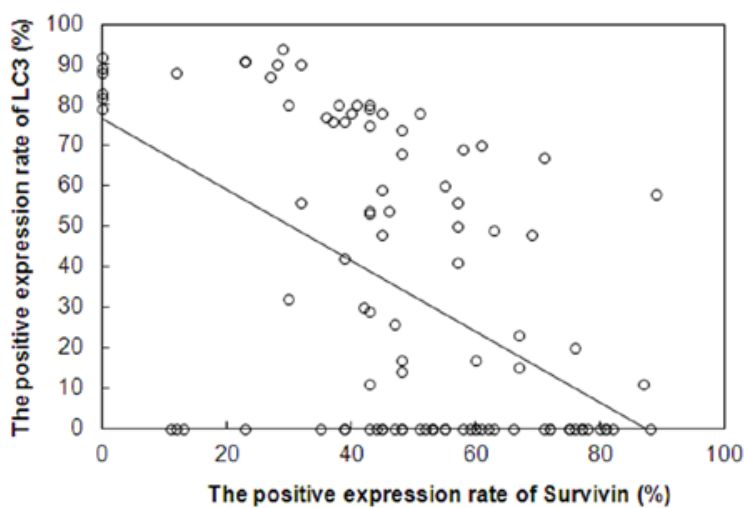

Figure 2. The relationship between LC3 and Bcl2 (A), survivin (B) by Pearson's correlation analysis. The scatter plot graph shows LC3 was negatively related to $\mathrm{Bcl} 2$ and survivin in SSCC.

tissues $(\mathrm{P}<0.005)$, the positive staining of survivin was $96 \%$, while no expression in normal tissues $(\mathrm{P}<0.005)$.

The expression level of LC3 was associated with the clinicopathological factors of SSCC. The clinical and pathological data of 100 SSCC patients is displayed in Table I. There was no statistical differences found between LC3 positive expression and the characteristics of age and disease site $(\mathrm{P}>0.05)$. However, LC3 overexpression in SSCC was strongly associated with thickness $(\mathrm{P}=0.012)$ and TNM stages $(\mathrm{P}=0.013)$, types $(\mathrm{P}=0.036)$ and lymph node metastasis $(\mathrm{P}=0.036)$ (Table $\mathrm{I})$.

The correlation of the expression of $L C 3, B c l 2$ and survivin in SSCC. As shown in Fig. 2, Pearson's correlation analysis shows the association between the expression of LC3 and Bcl2, LC3 and survivin in 100 cases of SSCC. Significant negative correlations were the expression of LC3 and Bcl2 ( $\mathrm{r}=-0.680, \mathrm{P}<0.05)$, LC3 and survivin ( $\mathrm{r}=-0.531, \mathrm{P}<0.05)$.

The effect of 5-FU and 3-MA on the proliferation of A431 cells is dose-dependent. The results of MTT assay showed that the inhibition rate of A431 cell proliferation was increased according to increase concentration of 5-FU with $0.1,1,10$ and $100 \mu \mathrm{g} /$ $\mathrm{ml}$ (Fig. 3A). Moreover, with increasing concentration of 3-MA with 2, 4 and $8 \mathrm{mmol} / \mathrm{l}$, the inhibition rates of proliferation in A431 cells increased (Fig. 3B). The increase of proliferation inhibition of A431 cells was time-dependent.

The expression of LC3 and inhibition effect of autophagy formation in A431 cells. The results of RT-qPCR showed that
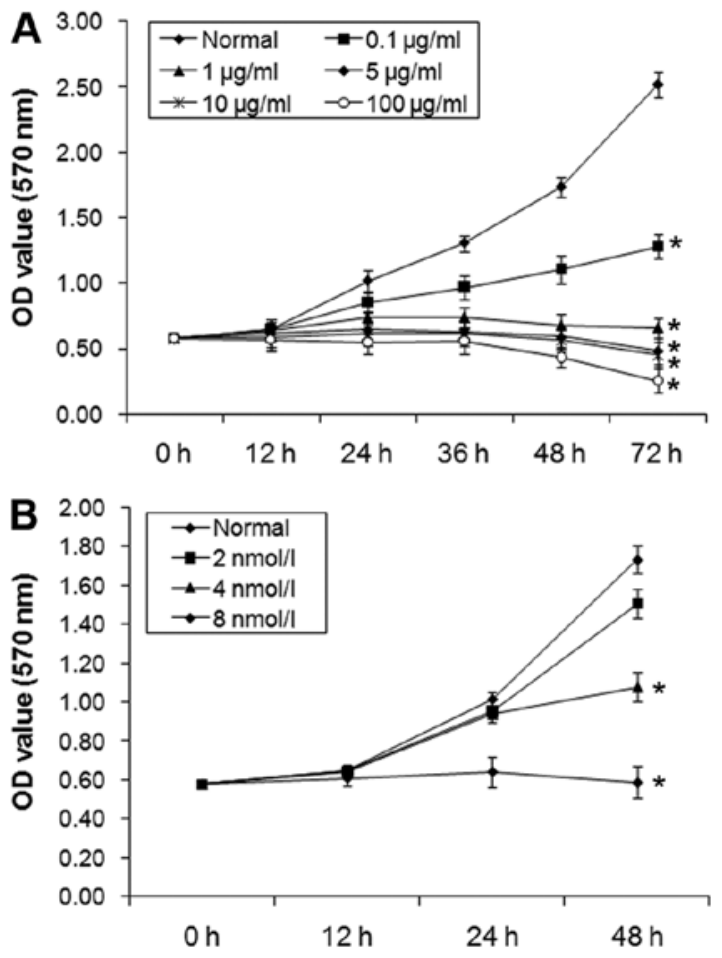

Figure 3. The effect of 5-FU and 3-MA on cell proliferation analyzed by MTT assay. (A) Growth curve of A431 cells for 5-FU treatment at 0, 24, 48, 72 and $96 \mathrm{~h}\left({ }^{*} \mathrm{P}<0.05\right)$. (B) Growth curve of A431 cells for 3-MA treatment at $0,24,48,72$ and $96 \mathrm{~h}\left({ }^{*} \mathrm{P}<0.05\right)$.

the mRNA level of LC3 was, respectively, 1.73- and 3.11-fold increased with the treatment of 5-FU (1 and $10 \mu \mathrm{g} / \mathrm{ml})$ for $24 \mathrm{~h}$, compared with normal group $(\mathrm{P}<0.05)$; and the mRNA level of LC3 was 25 and $69 \%$ decreased with the treatment of 3-MA ( 2 and $4 \mathrm{mmol} / \mathrm{l}$ ) for $24 \mathrm{~h}$, respectively, compared with normal group $(\mathrm{P}<0.05)$ (Fig. 4A).

The results of western blotting showed that the protein level of LC3 was 1.79- and 3.19-fold increased with the cells treated by 1 and $10 \mu \mathrm{g} / \mathrm{ml} 5$-FU for $24 \mathrm{~h}$, compared with normal group $(\mathrm{P}<0.05)$; and the protein level of LC3 was 22 and $72 \%$ decreased, respectively, with the cells treated by 2 and $4 \mathrm{mmol} / 1$ 3-MA for $24 \mathrm{~h}$, compared with normal group $(\mathrm{P}<0.05)$ (Fig. 4B).

The results of MTT, RT-qPCR and western blotting showed that the expression of LC3 was increased significantly in A431 cells treated with 5-FU at the concentration of $10 \mu \mathrm{g} / \mathrm{ml}$, while the inhibition rate were increased up to $40 \%$ whereas, treatment with 3-MA at the concentration of $4 \mathrm{mmol} / \mathrm{l}$, the inhibition rate was increased up to $20 \%$. Thus, $10 \mu \mathrm{g} / \mathrm{ml} 5-\mathrm{FU}$ and $4 \mathrm{mmol} / \mathrm{l} 3$-MA were used for further studies.

The expression of LC3 and inhibition of autophagy formation in A431 cells. The result of ICC showed that the expression level of LC3 in 3-MA+5-FU group was lower than other groups (Fig. 5A). MDC is a fluorescent substance, which is used to detect the occurrence of autophagy, as shown in Fig. 5B, there was some autophagy in the normal A431 cells. Compared with normal cells, the numbers of MDC-labeled cells in 5-FU treated group were increased, the cell autophagy was induced by 5-FU, but in the 3-MA treated group it was decreased. There was stronger punctate fluorescence of MDC 
A

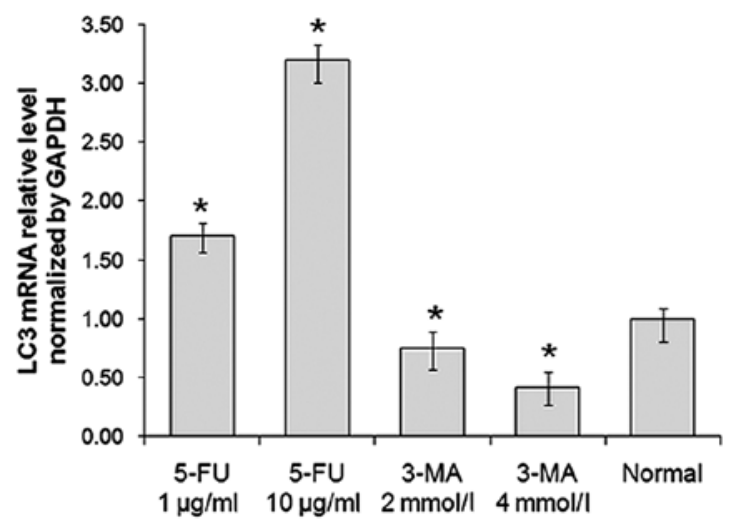

B
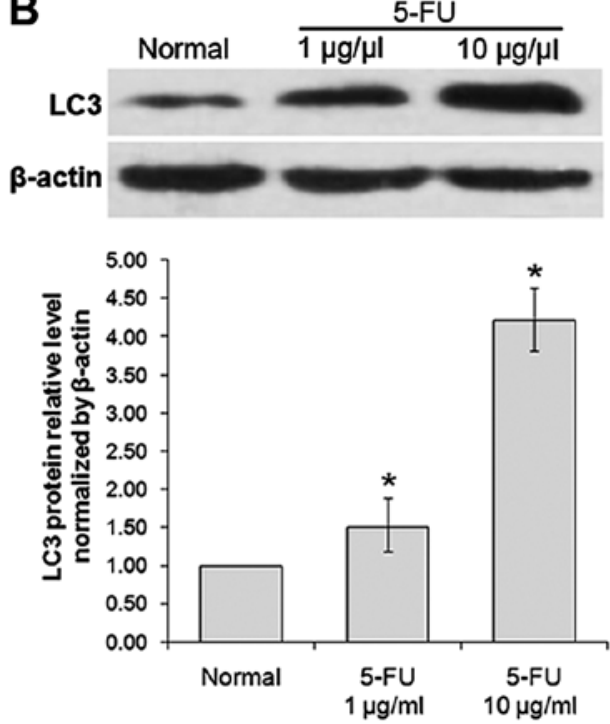

C
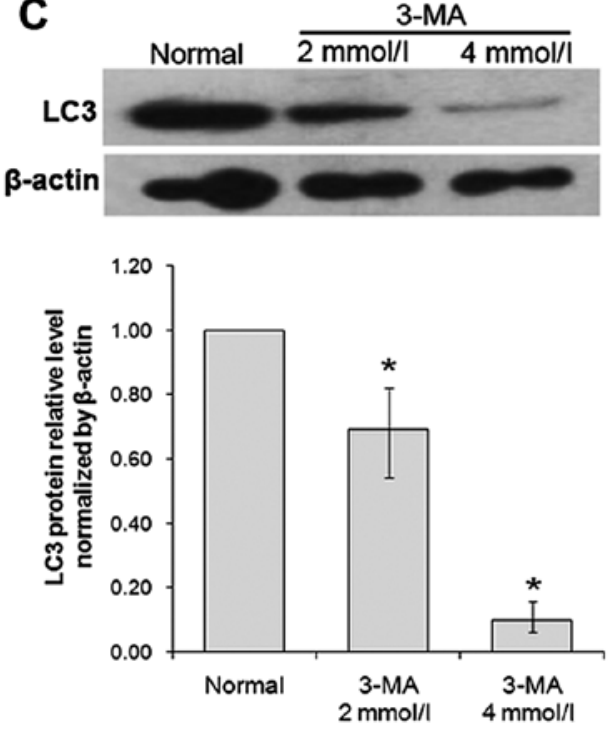

Figure 4. The expression of LC3 was affected by 5-FU and 3-MA treatment. (A) The effect of 5-FU and 3-MA on the mRNA level of LC3. (B) The effect of 5-FU and (C) 3-MA on the protein level of LC3 ("P<0.05 vs. normal cells).

than 5-FU, but there was no obvious difference in 5-FU+3-MA treated group.

Compared with normal cells, many autophagic vacuoles formed in the cytoplasm of A431 cells treated by 5-FU for $24 \mathrm{~h}$ revealed by transmission electron microscopy (Fig. 5C), and no evident autophagic vacuoles formed in 3-MA treated cells, the number of autophagosomes in 3-MA+5-FU treated group was less than 5-FU treated group.

Inhibition effects of 3-MA and/or 5-FU on the proliferation and apoptosis of A431 cells. Inhibition effect of A431 cell proliferation treated with 3-MA and/or 5-FU was detected by MTT assay. As shown in Fig. 6A, the proliferation of A431 was inhibited by 5-FU significantly, treated for $24 \mathrm{~h}$ the inhibition rate was $45 \%$, and there was no obviously inhibition in 3-MA treated group. Yet, in 5-FU+3-MA treated group, the inhibition rate was up to $68 \%$, the proliferation of A431 cells showed stronger inhibition than the other groups $(\mathrm{P}<0.05)$. In 5-FU+3-MA treated group, the inhibition rate was lower than in 5-FU $(\mathrm{P}>0.05)$. The results further illustrated that suppression effect of tumor cells could be re-enhanced efficiency by the method of autophagy specific inhibitor 3-MA-treated before chemotherapy drug 5-FU.

The expression of apoptotic genes $\mathrm{Bax}$ and $\mathrm{Bcl} 2$ were detected by RT-qPCR. As shown in Fig. 6B, compared with normal cells, the mRNA level of Bax was obviously increased, particularly when compared with 5-FU $(\mathrm{P}<0.05)$, and the mRNA level of $\mathrm{Bcl} 2$ in $3-\mathrm{MA}+5-\mathrm{FU}$ was decreased $(\mathrm{P}<0.05)$.

The effects of 3-MA and/or 5-FU on cell apoptosis were detected by Hoechst nuclear staining, as shown in Fig. 6C, typical cell apoptotic features with condensed nucleic were observed, and the AI in 3-MA+5-FU treated group was 46\%, which is significantly $(\mathrm{P}<0.05)$ higher than the $5-\mathrm{FU}$ treated group (28\%).

Inhibition effects of 3-MA and/or 5-FU on the migration and invasion of A431 cells. The migration inhibition effect of A431 cells treated with 3-MA and/or 5-FU was detected by wound healing assay (Fig. 7A). The wound healing rate of normal cells at 24 and $48 \mathrm{~h}$ was, respectively $(40.06 \pm 4.54) \%$ and $100 \%, 5-\mathrm{FU}$ treated cells was $(19.24 \pm 4.89) \%$ and $(34.13 \pm 3.80) \%$, 3-MA+5-FU treated cells was $(20.15 \pm 0.58) \%$ and $(22.20 \pm 2.29) \%$. Compared with normal cells and 5-FU treated group, the ability of cell wound healing was significantly $(\mathrm{P}<0.05)$ decreased.

The invasion inhibition effect of A431 cells treated with 3-MA and/or 5-FU was detected by Transwell assay (Fig. 7B). The cell invasion was inhibited by $10 \mu \mathrm{g} / \mathrm{ml} 5-\mathrm{FU}$ and $3-\mathrm{MA}+5-\mathrm{FU}$ treated cells were inhibited significantly $(\mathrm{P}<0.05)$. 


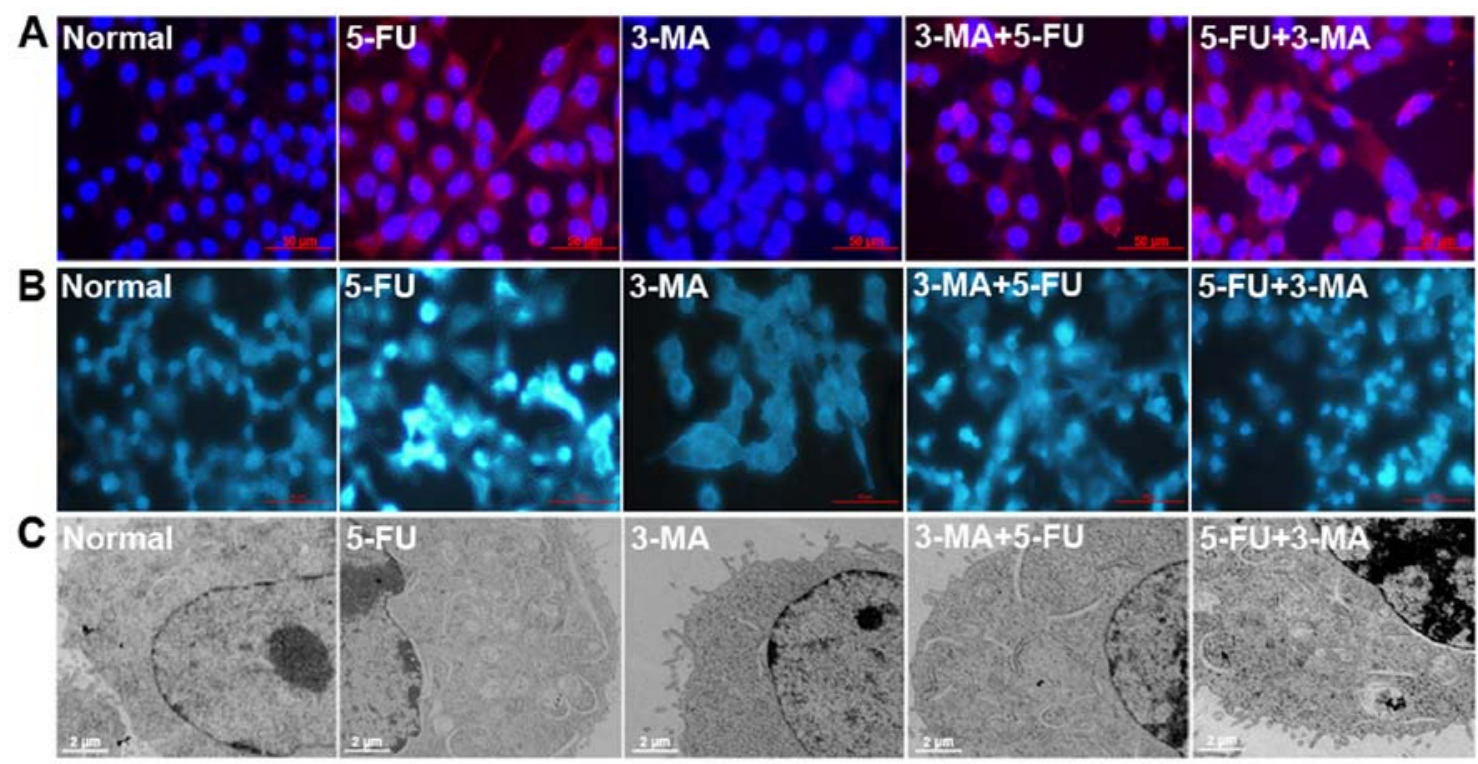

Figure 5. The expression of LC3 and inhibition effect of autophagy. (A) The expression of LC3 was determined by ICC in A431 cells with different treatments (magnification, x40). (B) Morphology of autophagosomes in A431 cells was detected by MDC staining (magnification, x40). (C) Images acquired by a transmission electron microscope (magnification, $\mathrm{x} 10,000$ ).
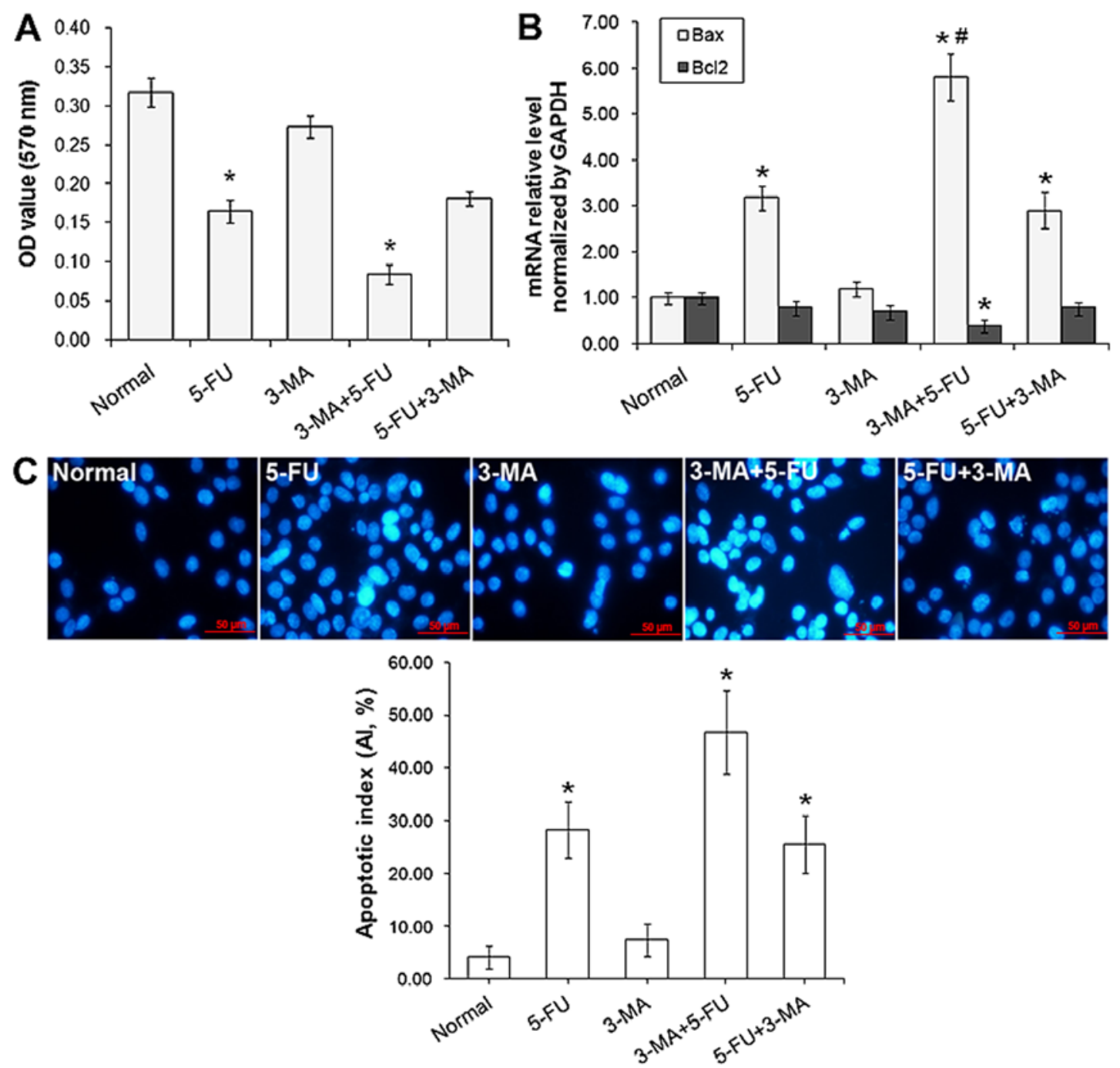

Figure 6. Inhibition effects of 5-FU and/or 3-MA on the proliferation and apoptosis of A431 cells. (A) The inhibition effect of 5-FU and/or 3-MA on A431 cell proliferation ( $\mathrm{P}<0.05$ vs. normal cells). (B) The expression level of Bax and $\mathrm{Bcl} 2$ in $\mathrm{A} 431$ cells with different treatments $\left({ }^{*} \mathrm{P}<0.05\right.$ vs. normal cells; ${ }^{*} \mathrm{P}<0.05$ vs. 5-FU treated cells). (C) Apoptotic cells were observed by Hoechst nuclear staining ( $\mathrm{P}<0.05$ vs. normal cells) (magnification, $\mathrm{x} 40$ ). 


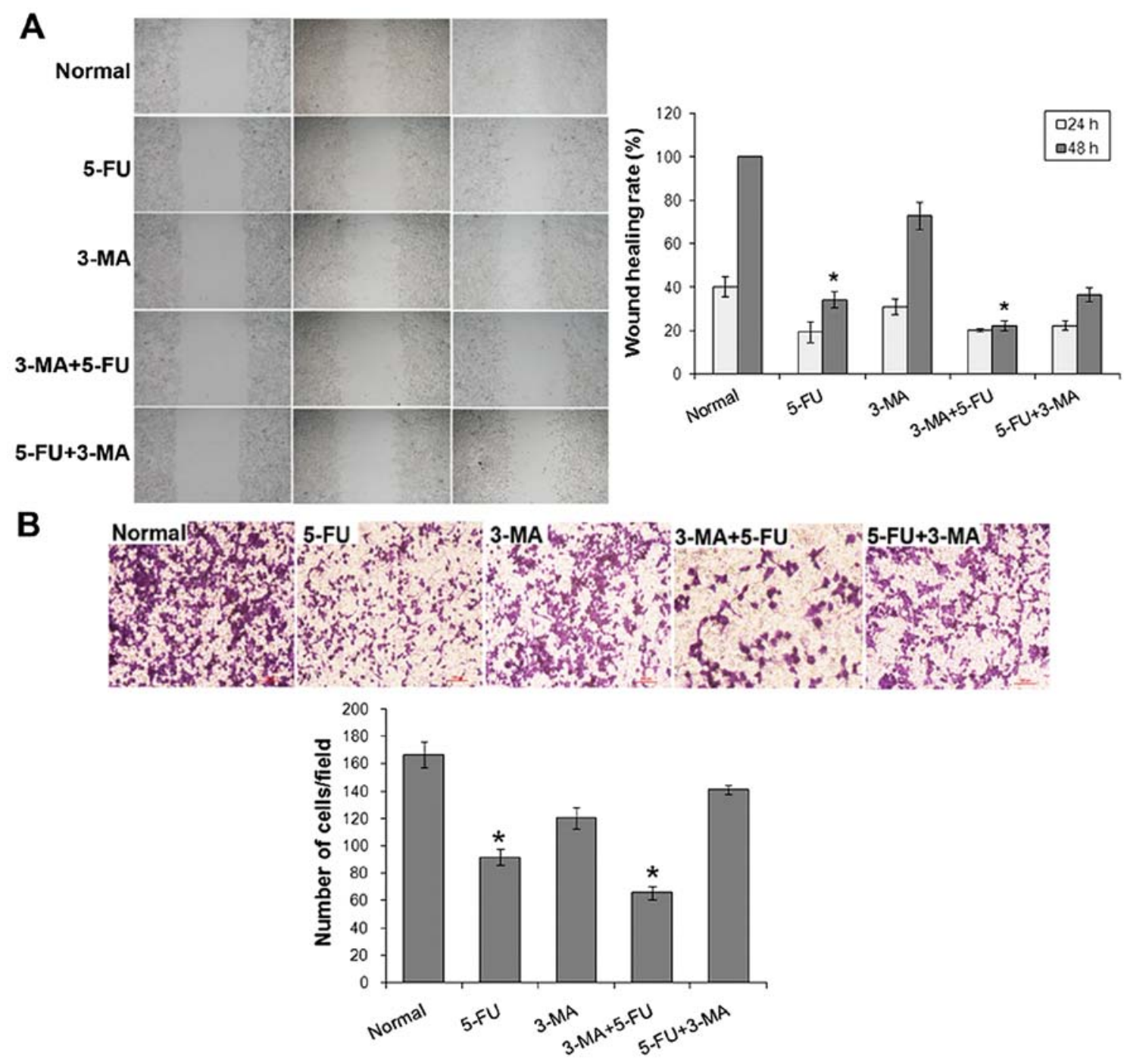

Figure 7. Inhibition effects of 5-FU and/or 3-MA on the migration and invasion of A431 cells. (A) Iinhibition effect of 5-FU and/or 3-MA on A431 cell migration ("P<0.05 vs. normal cells). (B) Inhibition effect of 5-FU and/or 3-MA on A431 cell invasion ("P $<0.05$ vs. normal cells).

\section{Discussion}

SSCC is the most common form of non-melanoma skin cancer, which can occur in normal skin, but often originate in precancerous lesions, particularly actinic keratosis, Bowen's disease, and also from actinic cheilitis, alphelasma, radiodermatitis, arsenical ketatosis, angioderma pigmentosum, chronic ulcer, burn scars and erosive oral lichen planus. SSCC is the second most common type of skin malignant tumors, and $>250,000$ cases are diagnosed per year (14). Most of the SSCC (80-90\%) develop from the skin of head and neck, is due to chronic ultraviolet light exposure for many years, mainly due to an outdoor occupation $(15,16)$. In most cases, SSCC is easily treated by simple excision or radiation therapy, however, locally advanced tumor recur in lymph nodes or distant metastasis $(17,18)$. SSCC could be easily transferred to local lymph nodes at the beginning, followed by the lung, liver and other organs. Transfer risk varies depending on the lesion location, the lips and ear risk is $10-15 \%$, the transfer rate of SSCC in penis, scrotum and anus is higher than in lips, in other exposed parts it is $2 \%$. Therefore, research on the mechanism is important for the SSCC treatment and prevention of recurrence and metastasis.
Autophagy is a common phenomenon in eukaryotic cells. The breakdown of cellular components promotes cellular survival during starvation by maintaining cellular energy levels, autophagy allows the degradation and recycling of cellular components (19), the autophagosome formed during this process, then fuses with a lysosome and its cargo is degraded and recycled. In many diseases, autophagy was seen as an adaptive response to stress which promotes survival, whereas it appears to promote cell death in other cases (20). Yet, there is no previous investigation concerning autophagy in SSCC. In the present study, we investigated the relationship between the autophagy related gene LC3 (the mammalian homologue of yeast Atg8, autophagy-related protein Atg8 is a protein encoded by 117 amino acid, it is expressed in the early independent cell membrane, autophagosome and the surface of autophagosome) and $\mathrm{Bcl} 2$ or survivin, the results show that the expression of LC3 is negatively correlated with $\mathrm{Bcl} 2$ and/ or survivin, revealing that the phenomena of autophagy also occurred in SSCC. Furthermore, the proliferation, motility, invasion and apoptosis of SSCC cells could be inhibited by 3-MA and/or 5-FU, particularly with the order of 3-MA treatment first and then 5-FU, suggested that 3-MA and 5-FU 
combination treatment may be an effective SSCC therapy via autophagy modulation.

\section{Acknowledgements}

The present study was supported by the Foundation of the Production-Study-Research prospective joint research programs of Jiangsu Province, China (no. BY 2013042-06), and from the Science Foundation of Nantong City, Jiangsu Province, China (nos. BK 2014001 and HS 2014004).

\section{References}

1. Cocchetto V, Magrin P, de Paula RA, Aidé M, Monte Razo L and Pantaleão L: Squamous cell carcinoma in chronic wound: Marjolin ulcer. Dermatol Online J 19: 7, 2013.

2. Chresta CM, Davies BR, Hickson I, Harding T, Cosulich S, Critchlow SE, Vincent JP, Ellston R, Jones D, Sini P, et al: AZD8055 is a potent, selective, and orally bioavailable ATP-competitive mammalian target of rapamycin kinase inhibitor with in vitro and in vivo antitumor activity. Cancer Res 70: 288-298, 2010.

3. Ogata M, Hino S, Saito A, Morikawa K, Kondo S, Kanemoto S, Murakami T, Taniguchi M, Tanii I, Yoshinaga K, et al: Autophagy is activated for cell survival after endoplasmic reticulum stress. Mol Cell Biol 26: 9220-9231, 2006.

4. Feldman ME, Apsel B, Uotila A, Loewith R, Knight ZA, Ruggero D and Shokat KM: Active-site inhibitors of mTOR target rapamycin-resistant outputs of $\mathrm{mTORC} 1$ and $\mathrm{mTORC} 2$ PLoS Biol 7: e38, 2009.

5. Stein M, Lin H, Jeyamohan C, Dvorzhinski D, Gounder M, Bray K, Eddy S, Goodin S, White E and Dipaola RS: Targeting tumor metabolism with 2-deoxyglucose in patients with castrateresistant prostate cancer and advanced malignancies. Prostate 70: $1388-1394,2010$

6. Alexander A, Cai SL, Kim J, Nanez A, Sahin M, MacLean KH, Inoki K, Guan KL, Shen J, Person MD, et al: ATM signals to TSC2 in the cytoplasm to regulate mTORC1 in response to ROS. Proc Natl Acad Sci USA 107: 4153-4158, 2010.

7. Ávalos Y, Canales J, Bravo-Sagua R, Criollo A, Lavandero S and Quest AF: Tumor suppression and promotion by autophagy. BioMed Res Int 2014: 603980, 2014.
8. Satoo K, Noda NN, Kumeta H, Fujioka Y, Mizushima N, Ohsumi Y and Inagaki F: The structure of Atg4B-LC3 complex reveals the mechanism of LC3 processing and delipidation during autophagy. EMBO J 28: 1341-1350, 2009.

9. Levine B, Sinha S and Kroemer G: Bcl-2 family members: Dual regulators of apoptosis and autophagy. Autophagy 4: 600-606, 2008.

10. McCarthy A, Marzec J, Clear A, Petty RD, Coutinho R, Matthews J, Wilson A, Iqbal S, Calaminici M, Gribben JG, et al: Dysregulation of autophagy in human follicular lymphoma is independent of overexpression of BCL-2. Oncotarget 5: 11653-11668, 2014.

11. Mita AC, Mita MM, Nawrocki ST and Giles FJ: Survivin: Key regulator of mitosis and apoptosis and novel target for cancer therapeutics. Clin Cancer Res 14: 5000-5005, 2008.

12. Livak KJ and Schmittgen TD: Analysis of relative gene expression data using real-time quantitative PCR and the $2^{-\Delta \Delta C_{\mathrm{T}}}$ method. Methods 25: 402-408, 2001.

13. Biederbick A, Kern HF and Elsässer HP: Monodansylcadaverine (MDC) is a specific in vivo marker for autophagic vacuoles. Eur J Cell Biol 66: 3-14, 1995.

14. Alam $\mathrm{M}$ and Ratner D: Cutaneous squamous-cell carcinoma. $\mathrm{N}$ Engl J Med 344: 975-983, 2001.

15. Veness MJ: Advanced non melanoma skin cancers of the head and neck: An overview on management. Cancer Forum 30 195-201, 2006.

16. Ramirez CC, Federman DG and Kirsner RS: Skin cancer as an occupational disease: The effect of ultraviolet and other forms of radiation. Int J Dermatol 44: 95-100, 2005.

17. de Lima Vazquez V, Sachetto T, Perpetuo NM and Carvalho AL: Prognostic factors for lymph node metastasis from advanced squamous cell carcinoma of the skin of the trunk and extremities. World J Surg Oncol 6: 73, 2008.

18. Cherpelis BS, Marcusen C and Lang PG: Prognostic factors for metastasis in squamous cell carcinoma of the skin. Dermatol Surg 28: 268-273, 2002.

19. Lin NY, Beyer C, Giessl A, Kireva T, Scholtysek C, Uderhardt S, Munoz LE, Dees C, Distler A, Wirtz S, et al: Autophagy regulates $\mathrm{TNF} \alpha-$ mediated joint destruction in experimental arthritis. Ann Rheum Dis 72: 761-768, 2013.

20. Patel AS, Lin L, Geyer A, Haspel JA, An CH, Cao J, Rosas IO and Morse D: Autophagy in idiopathic pulmonary fibrosis. PLoS One 7: e41394, 2012. 